\title{
COMPATIBILITY OF INDONESIA'S REGULATIONS ON SUBMARINE CABLE WITH UNCLOS 1982
}

\author{
Agustina Merdekawati, Swissitya Ajari, \\ Irkham Afnan Trisandi Hasibuan, and I Gusti Putu Agung
}

Faculty of Law, Universitas Gadjah Mada

J1. Sosio Yustisia No. 1, Bulaksumur, Sleman, D.I. Yogyakarta 55281

Email: agustina_merdekawati@ugm.ac.id; irkham.a@mail.ugm.ac.id;

\begin{abstract}
The special status of Exclusive Economic Zone of Indonesia (EEZ) raises a problem particularly related to the submarine cable laying activities. This study aims to analyze the compatibility of the marine location permit instrument under Law No. 32/2014 on Marine Affairs and Government Regulation No. 32/2019 on National Marine Spatial Planning (MSP) with UNCLOS 1982 in regulating submarine cable in the EEZ. This normative research shows that the marine location permit instrument regulating submarine cable laying activity in EEZ is incompatible with the provisions of UNCLOS 1982. In contrast, the MSP instrument is compatible and a suitable instrument to protect Indonesia's interests in the EEZ. The Government of Indonesia is advised to regulate an exemption clause for submarine cable installation in EEZ in the Draft of Government Regulation on Marine Location Permit; formulate and formalize 'prior notification' procedures by other countries in submarine cable laying activities in EEZ into laws and regulations; and publish the Government Regulation on Marine Spatial Planning and its annexes through the channels of relevant international organizations such as International Cable Protection Committee (ICPC) and Intergovernmental Oceanographic Commission (IOC).
\end{abstract}

Keywords: Indonesia EEZ, submarine cable laying, marine location permit, marine spatial planning.

\begin{abstract}
Abstrak
Kekhususan Zona Ekonomi Eksklusif Indonesia (ZEE) menimbulkan permasalahan terkait bentuk instrumen hukum yang dapat diterapkan oleh Indonesia untuk mengatur aktivitas pemasangan kabel bawah laut. Penelitian ini bertujuan untuk menganalisis kesesuaian instrumen izin lokasi laut dalam Undang-Undang 32/2014 tentang Kelautan; dan Peraturan Pemerintah 32/2019 tentang Rencana Tata Ruang Laut (PP RTRL) terhadap UNCLOS 1982 dalam mengatur aktivitas pemasangan kabel bawah laut di ZEE. Hasil penelitian normative ini menunjukkan bahwa instrumen izin lokasi laut tidak berkesesuaian dengan ketentuan UNCLOS. Sementara, instrumen rencana tata ruang laut berkesesuaian dengan ketentuan UNCLOS sehingga menjadi instrumen yang tepat untuk melindungi kepentingan Indonesia. Tim peneliti merekomendasikan kepada Pemerintah Indonesia untuk mengatur klausul pengecualian terhadap pemasangan kabel bawah laut di ZEE dalam Rancangan PP Izin Lokasi Laut; memformulasikan dan merumuskan prosedur 'prior notification' oleh negara lain dalam aktivitas pemasangan kabel bawah laut
\end{abstract}


di ZEE ke dalam peraturan perundang-undangan, dan memublikasikan eksistensi PP RTRL beserta lampiran-lampirannya melalui kanal organisasi-organisasi internasional terkait seperti International Cable Protection Committee (ICPC) dan Intergovernmental Oceanographic Commission (IOC).

Kata Kunci: ZEE, kabel laut, Izin Lokasi Laut, Rencana Tata Ruang Laut

\section{Background}

The vast technological development allows submarine cables to serve a vital role in various sectors such as communication and even the global economy. ${ }^{1}$ The optical submarine cable is often considered one of the international internet network's spearheads in communication. Tech giants such as Google, Microsoft, and Facebook are some of the companies which extensively utilize the submarine cables to provide internet access. ${ }^{2}$ Besides its role in communication, submarine cables also hold a critical role in the energy sector as a medium for transferring electricity.

Submarine cable is not limited as a medium to transfer energy within a country, but it is also allowing electricity transfer between countries. One example of such practice is between Malaysia and Singapore as they decided to construct a 10-KM long submarine power cable to transfer electricity from the power plant in Senibong Malaysia to Senoko Singapore. ${ }^{3}$

The United Nations Convention's drafters had anticipated the submarine cable's prominent role on The Law of the Sea 1982 (hereinafter UNCLOS 1982). At the time of UNCLOS 1982 formulation, they placed submarine cable laying as part of the freedom of the high seas to guarantee the right of all countries, both the coastal states and the landlocked states. ${ }^{4}$ Such freedom is accommodated in the Exclusive Economic Zone (hereinafter EEZ), continental shelf, and high seas.

Furthermore, the submarine cable regime under UNCLOS 1982 stipulates that when a state is exercising its right to lay submarine cables in EEZ and continental shelf of another coastal state, the consent of the latter is not required. ${ }^{5}$ This interpretation of the provision is based on the provision of Article 58 (1),

1 Further on the significance of submarine cables to the economy, see Asia-Pacific Economic Cooperation, "Economic Impact of Submarine Cable Disruptions," APEC Policy Support Unit, December 2012, Detecon Asia-Pacific Ltd., pp. 21-45.

2 CNN Indonesia, "Kominfo Bakal Tata Ulang Kabel Optik Bawah Laut", https://www.cnnindonesia.com/ teknologi/20180928170137-213-334042/kominfo-bakal-tata-ulang-kabel-optik-bawah-laut, accessed 12 December 2019.

3 Liputan 6, "Perusahaan Indonesia Garap Proyek Kabel Listrik Bawah Laut Malaysia-Singapura", https://www. liputan6.com/bisnis/read/4102965/perusahaan-indonesia-garap-proyek-kabel-listrik-bawah-laut-malaysiasingapura, accessed 28 November 2019.

4 UNCLOS 1982, Article 58 (1), and Article 87.

5 UNCLOS 1982 Article 79 paragraph (2) and (3); see also: Lionel Carter et al., The Relationship between Submarine Cables and the Marine Environment in Submarine Cables: The Handbook of Law and Policy, (2014), p. 183. 
which put submarine cable laying as freedom of all states.

The right to lay submarine cable becomes a polemic in Indonesia pursuant to the issuance of the Law No. 32/2014 on Marine Affairs (hereinafter Marine Affairs Law), which on Article 47 (1) mandates that "Every person who permanently utilizes sea space in territorial waters and territorial jurisdiction (wilayah yurisdiksi) ${ }^{6}$ must have Business Licensing related to utilization at sea." ${ }^{\prime 7}$ The polemic arises since Article 47 (1) of the Marine Affairs Law also obliges any activities conducted in the territorial jurisdiction (EEZ and continental shelf) to acquire a permit/ license.

Please note as of November 2020, the Marine Affairs Law has been amended with Law No. 11/2020 on Job Creation (Omnibus Law). Prior to the amendment, Article 47 (1) uses the term "location permit" as opposed to "Business Licensing" (Perizinan Berusaha). However, to avoid confusion due to the broad variations of business licensing in Indonesia, this paper uses the term "marine location permit" (izin lokasi laut) to refer to the location permit instrument to lay submarine cable.

Besides the provision to acquire a marine location permit, the Marine Affairs Law also mandates that marine spatial planning should also be issued in accordance with Article 43 , which manifested with the enactment of the Government Regulation No. 32/2019 on National Marine Spatial Planning (Rencana Tata Ruang Laut). The Government Regulation regulates the planning and the utilization of the marine spaces, including the territorial jurisdiction, i.e., contiguous zone, EEZ, and the continental shelf. ${ }^{8}$

In light of the government effort to regulate the territorial jurisdiction area, it should be noted that the UNCLOS 1982 gives sovereign rights to the coastal states to gain economic benefits from exploring, exploiting, conserving, and managing the natural resources found in the EEZ. ${ }^{9}$ On the other hand, UNCLOS 1982 also guarantees the other state's right to utilize EEZ of other states to exercise their right to lay submarine cable. ${ }^{10}$

Considering the provisions stipulated under the UNCLOS 1982 above, it is foreseeable that there would be overlapping interests, either between a coastal state and another state or between the other states in exercising their rights and freedoms. Therefore, to accommodate the states' interests, UNCLOS 1982 regulated that the coastal state must exercise its rights with due regard to other states' interests. ${ }^{11}$

6 This paper translates "wilayah yurisdiksi" to territorial jurisdiction. However, please note that the term "territorial jurisdiction" is not referring to territorial waters. According to Law No. 3/2008 on National Territory, Article 1 stipulates territorial jurisdiction comprises of EEZ, continental shelf, and contiguous zone.

7 The "Business Licensing" is regulated under Government Regulation No 24/2018 on Electronically Integrated Business Licensing Services.

8 Government Regulation No 32/2019 on Marine Spatial Planning, Article 2 (1).

9 UNCLOS 1982, Article 56 (1).

10 UNCLOS 1982, Article 58 (1), and Article 87.

11 UNCLOS 1982, Article 56 (2). 
UNCLOS 1982 also regulates that all states' rights and freedoms must be exercised with due regard to the coastal states' interests. ${ }^{12}$ It can then be concluded that the duty of due regard is reciprocal. However, there is no clear definition concerning the interpretation and the implementation of the due regard, which often resulted in causing conflicts among the states. ${ }^{13}$

Bearing in mind the formulation of the Marine Affairs Law, which mandates the implementation of marine location permit and the creation of maritime spatial planning, the question then is whether those provisions still enable the Indonesian government to accommodate the rights of other countries to exercise their freedom to lay submarine cables, particularly in the EEZ. This question is based on the fact that the Marine Affairs Law does not provide an exception clause on marine location permits and maritime spatial planning for foreign entities intended to lay submarine cables in the EEZ.

Consequently, the existence of marine location permit would position Indonesia as the 'legal owner' of the EEZ by enforcing its jurisdiction in prohibiting other countries from exercising their freedom to lay submarine cables as guaranteed by the UNCLOS 1982 . On the other hand, we must not disregard Indonesia's interest to regulate submarine cable laying activities conducted in its EEZ to avoid interference to its exercise of economic interests in the region. These economic interests may be disrupted by submarine cable laying activities if the cables traverse near a resource-rich area (unjustifiably interfering). ${ }^{14}$

Based on the background above, this research's focus is to examine whether the submarine cable laying regulations issued by the government of Indonesia to safeguard its economic interests in EEZ is compatible with the provisions of UNCLOS 1982. This research attempts to address the following questions:

1. whether the marine location permit in regulating submarine cable laying activity in EEZ is compatible with the provisions set in the UNCLOS 1982; and

2. whether the Marine Spatial Planning instrument in regulating submarine cable laying activities in the EEZ is compatible with the provisions set in the UNCLOS 1982.

This research is normative, utilizing secondary data consisting of primary, secondary, and tertiary legal materials. This study employs a qualitative method in processing the data to find the relevant norms.

12 UNCLOS 1982, Article 58 (1).

13 See PCA, Case No. 2011-03, “The Chagos Marine Protected Area Arbitration (Mauritius v. UK), Award of 18 March 2015; Also see ITLOS, Case No. 16, "Dispute concerning delimitation of the maritime boundary between Bangladesh and Myanmar in the Bay of Bengal (Myanmar v. Bangladesh)," Judgment of March 2012.

14 Mišo Mudrić, "Rights of States Regarding Underwater Cables and Pipelines," Australian Resources and Energy Law Journal, vol. 29, no. 2, 2010, p. 250. 
A. Compatibility of the Marine

Location Permit in Regulating

Submarine Cable Laying Activity in the EEZ with UNCLOS 1982

Marine location permit is stipulated in Article 47 (1) of Marine Affairs Law. The marine location permit concept is similar to the location permit concept under Law No. 27/2007 as amended by Law No. 1/2014 on Small Islands and Coastal Areas Management, which separates the scope of the location permit from the resource management license.

Nonetheless, the main difference between the marine location permit stipulated under the Marine Affairs Law and the location permit stipulated under Law No. 27/2007 (in conjunction with Law No. 1/2014) is on the scope of the sea area regulated. The Marine Affairs Law regulates location permit is required for any activities conducted in territorial waters and territorial jurisdiction waters.

Based on the formulation of Article 47 (1) on the Marine Affairs Law, it can be interpreted that if other states intend to lay submarine cable in Indonesian EEZ, they are required to obtain a marine location permit first. That is the case as there is no exclusion for submarine cable laying by other states conducted in the EEZ. However, Article 47 (4) mandates that the provisions concerning marine location permits in the territorial waters, territorial jurisdiction, and the procedure for the imposition of administrative sanctions are to be regulated with a Government Regulation.

As of January 2021, the Indonesian government has not issued the Government Regulation regulating the marine location permit in the territorial jurisdiction as mandated by Article 47 (5) of the Marine Affairs Law in conjunction with Law No 11/2020. Despite the absence of an implementing instrument regulating the marine location permit in the territorial jurisdiction (i.e., EEZ), the compatibility of Article 47 (1) of the Marine Affairs Law needs to be examined in accordance with the provisions of UNCLOS 1982, particularly regarding the rights of all states to conduct submarine cable laying activity in the high seas, including in the foreign territorial jurisdiction waters. ${ }^{15}$

The compatibility of marine location permit is UNCLOS is important to be discussed as it also correlates with the implementation of Marine Spatial Planning policy (hereinafter MSP). Pursuant to the amendment by Law No 11/2020 on Job Creation, the Marine Affairs Law governs that the marine location permit is to be issued in accordance with the MSP. ${ }^{16}$ Therefore, we can infer that the marine location permit is aimed to be the implementing instrument of MSP in Indonesia.

15 Article 58 (1) of UNCLOS 1982 stipulates that: "in the exclusive economic zone, all States, whether coastal or land-locked, enjoy, subject to the relevant provisions of this Convention, the freedoms referred to in Article 87 of navigation and overflight and the laying of submarine cables and pipelines, and other internationally lawful uses of the sea related to these freedoms, such as those associated with the operation of ships, aircraft and submarine cables and pipelines, and compatible with the other provisions of this Convention."

16 Law No. 32/2014 on Marine Affairs, Article 47A (1). 
Considering the coastal state's sovereign rights in the EEZ is exclusive to the economic exploitation in accordance with the provision stipulated under Article 56 (1) of the UNCLOS 1982. The coastal state does not own the EEZ waters but merely a state with the sovereign right regarding the enjoyment of natural resources located in the EEZ. ${ }^{17}$ It contrasts with territorial waters, where the coastal state has sovereignty and is the territorial sea's legal owner. The status of the coastal state and the other states in the EEZ is equal when it comes to ownership, where there is no prima facie paramountcy or pre-eminence. ${ }^{18}$

The relation between the coastal state and the other state in the EEZ under UNCLOS 1982 is regulated under the "due regard" concept. The concept of the due regard itself proves the neutrality of the provisions under the UNCLOS 1982 which does not in favor of either the coastal states or other states which possess an interest in the EEZ by explicitly creating balanced rights and obligations to all party. ${ }^{19}$ Consequently, the relations between states in the EEZ is based on legal equality, in which UNCLOS 1982 obliges the duty of mutual due regard in governing relationships between states in the EEZ. ${ }^{20}$
The mutual due regard principle promotes a balance of right and duty between the parties by encouraging every party to consider and respect the other state's interest. The application of this principle was demonstrated in the case of the Chagos Maritime Protected Area, where the arbitrators interpret that the principle of due regard obliges every state who exercises its freedom to consider the rights and interests of the other states. In that case, the United Kingdom was obliged to take into account Mauritius's rights and interests. ${ }^{21}$

Furthermore, there is no universally applicable formulation on the implementation of due regard obligations in the arbitrators' view. $^{22}$ Therefore, we may infer that the formulation of provisions in the UNCLOS 1982 does not limit the manifestation of the exercise of due regard, so long as the state can demonstrate that it has considered the existence and the right of the other states in the policy-making process or making decisions.

The pattern of the exercise of rights by coastal states and other states in EEZ as regulated in UNCLOS 1982 is shown in Illustration 1.

\section{UNCLOS 1982, Article 55.}

18 See ITLOS, Case No. 2 M/V "SAIGA" (Saint Vincent and the Grenadines v. Guinea), Separate Opinion of Judge Laing, par. 52.

19 Julia Gaunce, On the Interpretation of the General Duty of "Due Regard," Ocean Yearbook, 2017, Vol. 32, p. 8.

20 Malcolm N. Shaw, 2014, International Law 7th Edition, Cambridge University Press, Cambridge, p. 155.

21 PCA, Case No. 2011-03, The Chagos Marine Protected Area Arbitration (Mauritius v. UK), Award of 18 March 2015, para. 519.

22 Ibid. 


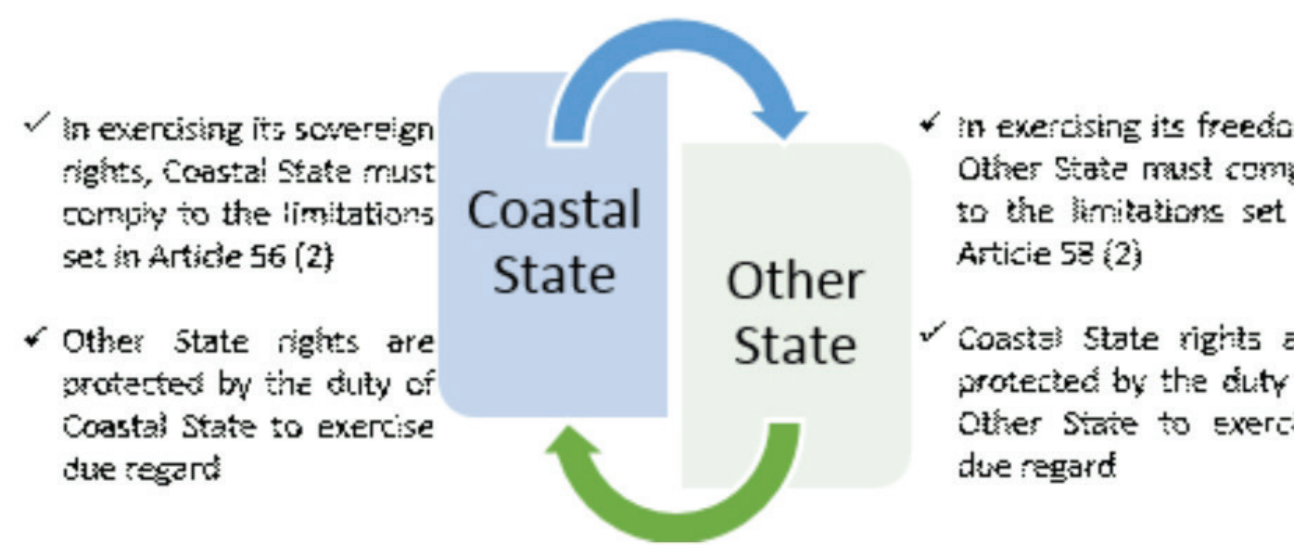

\section{Illustration 1. Relations between coastal state and other states in the EEZ}

Source: authors

As shown in the illustration above, UNCLOS 1982 desires all states to exercise their rights proportionally to guarantee that the other states' rights will also be fulfilled. ${ }^{23}$ Meanwhile, in a dispute between the states, UNCLOS 1982 desires that the parties seek a fair solution for both parties. ${ }^{24}$

The act of the coastal state to regulate marine location permits can be seen as an act to position itself higher than the other countries. Referring to Law No. 30/2014 on Government Administration, a permit (vergunning) is a decision issued by the official as a form of approval for a request issued by society according to statutory regulations. ${ }^{25}$ Therefore, it can be construed that the implementation of marine location permit in the EEZ would position the coastal state as the owner of the marine space, which entitled them the right to prohibit other states from utilizing the space, which in this case is the right of the other state to conduct submarine cable laying activity. ${ }^{26}$

This practice of issuing location permit is contrary to the right of the coastal states in EEZ under UNCLOS 1982, which is limited to the sovereign right, and it also violates the right of other states to exercise the freedom granted by the UNCLOS 1982 to lay submarine cables.

The conclusion above arises since referring to the definition of the term "permit," the marine location permit prohibits any person from conducting any submarine cable laying activity within Indonesia jurisdiction marine territory without the marine location permit. It should be noted that such regulation may result in the removal of every person's right

23 Hasjim Djalal, 2015, 'Due Regards' and Abuse of Rights' in UNCLOS, in Shicun Wu et al., 2015, UN Convention on the Law of the Sea and the South China Sea, National Institute for South China Sea Studies, Ashgate Publishing Limited, pp. 65-71.

24 UNCLOS 1982, Article 59.

25 Law No. 30 of 2014 on Governance Administration, Article 1.

26 This interpretation relates to the provision set under Article 300 of the UNCLOS, which regulates that states are obliged to exercise their right, jurisdiction, and freedom entitled in a manner that does not constitute "abuse of right." Abuse of rights can be defined as unnecessary actions or unilateral actions that result in losses to other parties. See: Mišo Mudrić, Op. Cit., pp. 254-255. 
(in this case, including the right of the other states) to conduct submarine cable laying activity, which granted the status as one of the freedoms that do not require permit or consent from the coastal states. ${ }^{27}$

Moreover, Indonesia's action in mandating other states to request a permit before conducting submarine cable laying activity can be interpreted as a violation of the duty of due regard, which UNCLOS 1982 regulates that in exercising its right in the EEZ, the coastal state shall have due regard to the rights of other states. ${ }^{28}$ It can be implied that marine location permit does not consider the presence of other states' right and freedom in the territorial jurisdiction waters, considering such permit equalizes that every activity relating to the use of marine space in the territorial jurisdiction is by default prohibited unless the government of Indonesia grants such permit.

The instrument's implementation will only get even more complicated as it will concurrently align with the licensing regime that applies in Indonesia, which would involve tariffs charged to the permit's applicant. The tariffs themselves classify as Non-Tax Revenue. ${ }^{29}$ Therefore, the implementation of marine location permits in the territorial jurisdiction, in this case regarding submarine cable laying activity, should be exempted from the implementation of marine location permit regulation, which is yet to be issued.

We may imply that the Indonesian government's urgency to implement a marine location permit instrument arises from the intention to protect Indonesia's interests, particularly the economic interests in the territorial jurisdiction as stipulated under the Marine Affairs Law. ${ }^{30}$ Such interests need to be protected, although according to the research findings thus far, the marine location permit instrument is incompatible with the provisions of UNCLOS 1982. Therefore, the government needs other instruments to protect Indonesia's interests in EEZ that are compatible with UNCLOS 1982 provisions.

The following discussion will provide an analysis on the compatibility of the marine spatial planning (hereinafter MSP) instrument with the provisions of UNCLOS 1982.

\section{B. The Compatibility of Marine Spatial Planning Instrument in Regulating Submarine Cable Laying Activities in the EEZ with UNCLOS 1982}

Based on the previous discussion, it is concluded that Indonesia's marine location permit for submarine cable laying activity

27 Lionel Carter, Loc. cit.

28 UNCLOS 1982, Article 56 (2).

29 This affirmation is necessary since, according to the revision draft of Government Regulation Number 75/2015 on Types and Tariffs of Non-Tax State Revenues, it will govern that submarine cable licensing is one subject of non-tax revenue. The Regulation draft revision needs to affirm that the installation of submarine cables subject to non-tax revenue must be exempted from submarine cables in the territorial jurisdiction area (i.e., in EEZ and continental shelf).

30 Law No. 32 of 2014 on the Sea, preamble section a - c. 
in EEZ is conflicting with the provisions stipulated in the UNCLOS 1982, particularly the provisions on the ZEE legal status and other states' freedom. Therefore, the government needs other instruments to protect Indonesia's interests in EEZ that are compatible with UNCLOS 1982 provisions.

Indonesia has adopted Government Regulation No. 32/2019 on Marine Spatial Planning. The regulation's scope covers territorial water and territorial jurisdiction waters, including the MSP for submarine cable routes. ${ }^{31}$ The regulation itself acts as a form of Indonesia's effort to manage marine space to protect the resources and the environment and optimize the utilization of resources and activities in the marine space on a national and international scale. ${ }^{32}$

Theoretically, MSP policy is regarded as an effort to establish a more rational use of marine space and a relationship between one utilization purpose and the other, balance the need for development with the need to protect the environment, and achieve socio-economic goals in a planned manner. ${ }^{33}$

The assessment of the MSP instrument's compatibility with the provisions stipulated in the UNCLOS 1982 showed that it is a compatible instrument to be implemented by a coastal state to exercise its duty of due regard as obliged by the UNCLOS 1982. However, it should be noted that such a conclusion does not imply that all forms of MSP may be the optimal form in implementing the duty of due regard.

The conclusion is rather based on the basic concept of MSP that accommodates the interests of all the relevant stakeholders; thus, making it a potential instrument to be implemented by a coastal state to exercise its duty of due regard as obliged by the provisions of UNCLOS 1982, while still being able to protect its interests in the EEZ. This research also examines Indonesia's MSP with the basic MSP concept to see whether Indonesia's MSP achieves the same compatibility.

This part of the discussion is not aimed to assess the compatibility of the MSP instrument in all its forms of implementation by other coastal states. The assessment is based on the theoretical concept of MSP as an optimal instrument to exercise the duty of due regard under several notes in Indonesia's implementation to ensure its compatibility with the provisions of UNCLOS 1982.

31 Government Regulation No. 32/2019 on Marine Spatial Planning, Article 2 (1).

32 Ibid., preamble section b.

33 Generally, the MSP policy is a form to create a more rational utilization of marine space and connect one utilization with the other to maintain the balance of sustainable development with the need to conserve the environment and manifest planned social purposes. Since UNCLOS 1982 was established, there has been a paradigm change regarding the utilization of marine space, where the utilization itself does not only connects to the natural resources and their consequences in the sea but also reaches spatial aspects. In the past few decades, the national, regional, and global maritime policy has centered on integrating sea management regarding the environmental and economic aspects. The MSP manifestation is the creation of a specific marine spatial zone dedicated to one or more activities that utilize specific marine spaces. See: A. O. Tuda et al., "Resolving Coastal Conflicts using Marine Spatial Planning," Journal of Environmental Management, Vol. 133, 2013, pp. 59-68. 
This research assumes that coastal states have the right to implement MSP, including in the territorial jurisdiction waters (particularly in the EEZ). ${ }^{34}$ The implementation of MSP policy is already a common practice by the coastal states, although the policy's implementation could be varied between one coastal state with the others (including the scope of implementation, i.e., whether it also governs the marine space in the EEZ).

At least 70 countries have initiated the implementation of MSP policy, whether it is still in the planning stage or already being implemented and re-evaluated. ${ }^{35}$ Although the policy's implementation may be varied between countries, the aims of the policy are commonly the same, i.e., to optimize the utilization of the marine space. ${ }^{36}$
Given that countries around the world have commonly practiced the implementation of the MSP policy in the EEZ in the last two decades, and even the implementation itself is encouraged by the international organization such as the Intergovernmental Oceanographic Commission (IOC) and the United Nations Educational, Scientific and Cultural Organization (UNESCO); ${ }^{37}$ it can be concluded that the practice of implementing MSP policy in the EEZ is a common practice that has been widely accepted by countries. ${ }^{38}$

The MSP policy is closely related to the implementation of the coastal state's sovereign right to protect its economic interests and the marine environment. ${ }^{39}$ On the other hand, MSP may also be beneficial for the other states (i.e., foreign states who utilize marine

34 According to the formulation of Article 56 (1), it is inferred that UNCLOS 1982 does not limit the forms of economic benefits that a coastal state may exploit in the EEZ. The Article regulates further that coastal state has: "sovereign right for the purpose of exploring and exploiting, conserving, and managing the natural resources, whether living or non-living, of the waters superjacent to the seabed and of the seabed and its subsoil. These sovereign rights apply to other activities for economic exploitation and exploration, such as the production of energy from water, currents, and winds." The term 'such as' shows that UNCLOS 1982 does not limit any activity permitted to the coastal states regarding its economic interest. Based on the formulation of Article 56 (1) and considering the MSP policy concept to optimize marine spatial utilization to scale up economic interest sustainably, it can be concluded that the implementation of MSP policy is in line with the sovereign right guaranteed by the UNCLOS 1982. Therefore, it can be considered that Indonesia can implement the MSP policy in its EEZ. See: Frank Maes, "The International Legal Framework for Marine Spatial Planning," Marine Policy, vol. 32, no. 5, p. 801.

35 Intergovernmental Oceanographic Commission - United Nations Educational. Scientific, and Cultural Organization, Marine Spatial Planning Programme, http://msp.ioc-unesco.org/world-applications/overview/.

36 A. O. Tuda, et al., loc. Cit.; see also: Ehler C., and Douvere F., "Visions for a Sea Change, Report of the first international workshop on marine spatial planning," Intergovernmental Oceanographic Commission and man and the biosphere programme, IOC Manual and Guides No. 48 IOCAM Dossier No. 4, UNESCO, 2007.

37 MSP policy is necessary for determining the efficiency of the utilization of marine spaces, which further correlates with the coastal state's economic advantage. See: V. Becker-Weinberg, "Preliminary Thoughts on Marine Spatial Planning in Areas beyond National Jurisdiction," The International Journal of Marine and Coastal Law, Vol 32, No 3, 2017, pp. 570-588; Further see: Ehler et al., 2009, "Marine Spatial Planning: A Step-by-Step Approach Toward Ecosystem-Based Management," Intergovernmental Oceanographic Commission and Man and the Biosphere Programme, IOC Manual and Guides No. 53, ICAM Dossier No. 6 , Paris, UNESCO, available online on https://unesdoc.unesco.org/ark:/48223/pf0000186559.

38 Ibid.

39 Charles N. Ehler, “An International Perspective on Marine Spatial Planning Initiatives," Environments Journal, Vol. 37, No. 3, 2010. pp. 9-20. 
space) as a guideline to perform their duty of due regard in the exercise of their rights and freedoms as stipulated in the UNCLOS 1982. Therefore, it can be understood that the MSP policy can be a platform for a coastal state and other states to interact harmoniously in terms of marine space utilization, making rights and duties of each party to be respected and accommodated.

Consequently, it also needs to be considered that UNCLOS 1982 entitles every state the right to conduct submarine cable laying activity in the EEZ as an extension of the freedom of the high seas. ${ }^{40}$ Thus, in implementing MSP policy on its EEZ, Indonesia should consider the other states' rights, including the freedom to install submarine cable. Moreover, during the MSP planning stage, the other states' right to install submarine cable in the EEZ should be considered as the exercise of the duty of due regard.

Based on the previous discussion, it is understood that the UNCLOS 1982 does not define nor limit the exercise of the duty of due regard and the form of its implementation. However, based on the interpretation of the Permanent Court of Arbitration (PCA) on the case of Chagos Marine Protected Area
(Mauritius v. United Kingdom), and the interpretation of the International Tribunal for the Law of the Sea (ITLOS) on the Bangladesh v. Myanmar Case, it is concluded that there is no universal formulation concerning the implementation of the duty of due regard by states. $^{41}$

The interpretation above is in line with UNCLOS 1982 that obliges all states to respect other states' rights in the EEZ. Article 56 (2) and Article 58 (3) stipulate that the coastal states and the other states are equal, which results in the importance of the duty of due regard to balance every state's rights. ${ }^{42}$ It can be concluded that the UNCLOS 1982 does not put a limit on how each state should manifest the duty of due regard, thus opens the possibility for the coastal states to utilize MSP as the instrument to exercise their duty of due regard.

UNCLOS 1982 stipulates that in exercising its sovereign right in the EEZ, coastal states are given the jurisdiction to regulate the activity in their EEZ as long as the regulation is related to the rights to explore and exploit natural resources within the area. ${ }^{43}$ Referring to Article 79 (2) of the UNCLOS 1982, the coastal state is entitled to take reasonable

40 UNCLOS 1982, Article 58 (1).

41 It could be interpreted that the duty of due regard implementation is dependent on the context of the overlapping interests and the alternative recourse available to each of the parties. However, in exercising the duty of due regard, the state must consider: a) to balance overlapping rights; b) consider other alternative means; c) to evaluate the need to consult with the other state concerned (it is not obliged to reach an agreement). Further, the choice concerning how the duty of due regard should be implemented is the state's discretion and requires no concurrence of the other state concerned. Further see ITLOS, "Dispute concerning delimitation of the maritime boundary between Bangladesh and Myanmar in the Bay of Bengal (Bangladesh/Myanmar)," Judgment of 14 March 2012, para. 475-476; Also see: PCA, "The Chagos Marine Protected Area Arbitration (Mauritius v. UK)," Award of 18 March 2015, para. 519.

42 Julia Gaunce, op.cit., p.8.

43 Tullio Treves, "Coastal States' Rights in the Maritime Areas under UNCLOS," Brazilian Journal of International Law, Vol. 12, No. 1, 2015, p. 41. 
measures to protect its right to gain economic benefits from the area. ${ }^{44}$ Concerning such rights, the implementation of MSP policy can be categorized as an act by the coastal state to safeguard its economic interests by ensuring that the marine space is rationally (optimally) used.

In line with Indonesia's economic interests in the EEZ, the MSP instrument should be aimed to protect Indonesia's interest by designating and securing marine space into several zones based on some specific designations (e.g., fishing, sea lanes). It may also exclude some zones from being traversed by submarine cables that are intended for other activities (e.g., exploration and exploitation of natural resources); even when there are no such activities in the area in the meantime (i.e., securing the area for future exploration and exploitation activities).

According to the consideration stated above, the designation of specific marine spaces function (zoning) should not be based on the activity already being conducted or is currently existing (as if first-come, firstserved basis) per se. Rather, it should be based on the area's mapped potential already being identified or declared for, even though the de facto utilization activities in the zones (according to its identified potential or declared use) have not been carried out. As a result, the MSP instrument can be used to safeguard Indonesia's interest in the EEZ while still accommodating the fulfillment of other states' right to lay submarine cables.

Scenario 1, with MSP

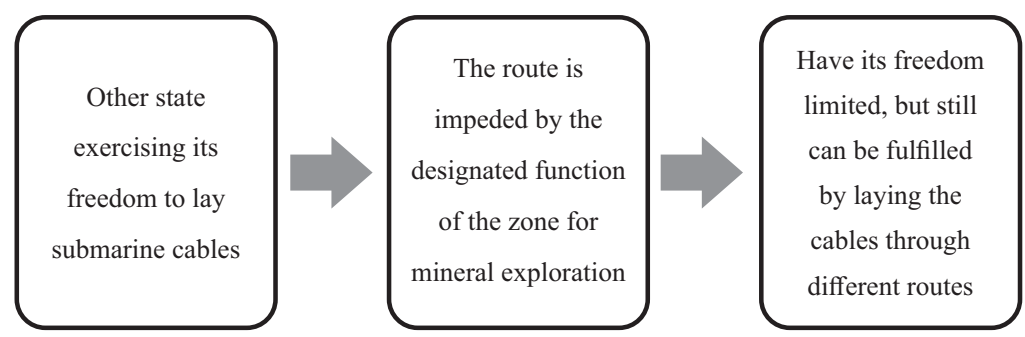

Scenario 2, without MSP

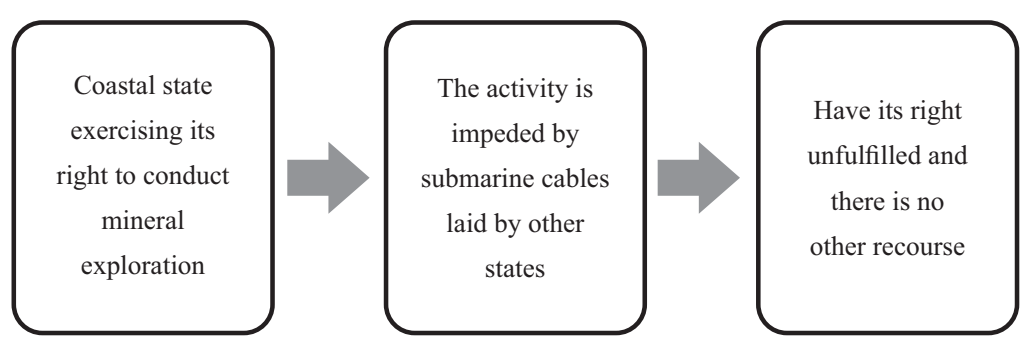

Illustration 2. The role of MSP in creating a balanced exercise of rights in the EEZ

Source: authors

\footnotetext{
44 Although Article 79 (2) of UNCLOS 1982 is the Continental shelf's regulatory regime, the provision contained a general principle that applies to the EEZ regulatory regime. See: G.A. Sgouros et al., "Cable and Pipeline Corridors under the Legal Framework of UNCLOS End the energy Treaty: Geopolitical Considerations at the Eastern Mediterranean Sea," Regional Science Inquiry, vol. 9, no. 1, 2017, p. 76.
} 
According to the illustration above, it can be understood that the MSP instrument can create a balance between the interest of the coastal states and the interest of other states. Even though the coastal state may declare (designate) the areas to be exempted from any submarine cable laying activity, it is not meant to injure other states' right of such right. That is the case because the other states would still be able to exercise such right in the other zone that is available or designated for submarine cables routes.

Comparatively, without the MSP instrument, the coastal state interest may be injured by cable laying activity, considering UNCLOS 1982 does not require the foreign states to acquire a permit from the coastal state when conducting such activity. The likelihood for the submarine cable route to traverse through an area rich in the natural resource cannot be disregarded, ${ }^{45}$ as it would compromise the right of the coastal state to utilize such resources. ${ }^{46}$

In regard to the designation of particular marine space for submarine cables, the MSP can also be considered as the intention of the coastal state to safeguard the submarine cables from possible danger by exempting the area for other purposes, therefore eliminating the possible overlap of marine space usage that may put the cables in the risk of being damaged. ${ }^{47}$ As established previously, submarine cables have an enormous impact on both the cable recipients (landing state) and the global economy. ${ }^{48}$

Damages to submarine cable are caused mostly by fishing activity and contact with ship's anchors. Such occurrences could have been prevented by avoiding the overlapping activities in such areas. ${ }^{49}$ The notion of protecting submarine cables is also essential for all parties, as the damages to the cables would deal a widespread and massive impact on many stakeholders' interests. ${ }^{50}$ In conclusion, regulating marine space utilization can be considered the coastal state's intention to protect its economic interest and the other state interests that benefited from the cables.

Damage to submarine cables due to Indonesia's shipping activities once occurred in 2013, where within two months, three incidents occurred related to submarine cables being hit by ships anchor. ${ }^{51}$ Besides damage from boat or fishing activity, submarine cables

45 Lionel Carter, et al., Op. cit., p 183.

46 Yoshinobu Takei, "Law and Policy for International Submarine Cables: An Asia-Pacific Perspective," Asian Journal of International Law, Vol.2, No. 2, 2012, p. 210.

47 Lionel Carter et al., Loc cit.

48 Mick P. Green, and Douglas R. Burnett, "Security of International Submarine Cable Infrastructure: Time to Rethink?" International Cable Protection Committee, Available online on https://www.iscpc.org/information/ government-and-law/; See: "Economic Impact of Submarine Cable Disruptions," APEC Policy Support Unit, December 2012, Detecon Asia-Pacific Ltd.

49 Robert Beckman, "Submarine Cables - A Critically Important but Neglected Area of the Law of the Sea," ISIL Conference, January 2010, p. 12.

50 Ibid., p. 2.

51 Mutia Ramadhani, "Indonesia-Singapore Underwater Networks Disrupted after Anchor Snags Cable," Republika, Friday, 18 October 2013, https://republika.co.id/berita/muvd9b/indonesiasingapore-underwaternetworks-disrupted-after-anchor-snags-cable, Accessed on 27 January 2020. 
are also prone to theft. It is projected that up to 10 billion Rupiahs worth of cable components have been stolen in the same year. ${ }^{52}$ Therefore, designating certain zones for submarine cable routes would ease the coastal states in guarding the cables (i.e., with sea patrol) from accidental and intentional damage. The effort to protect submarine cables is one of Indonesia's considerations in designing MSP policy. ${ }^{53}$

The synchronization between the implementation of MSP policy with the application of the duty of due regard can be assessed by examining whether, in designing the MSP policy, the coastal state also considers other states' rights in the EEZ. ${ }^{54}$ The implementation of MSP policy cannot be interpreted as an act of the coastal state to prioritize its interests merely but must be interpreted as an act of the coastal state to safeguard its interests and the interests of all other marine space users. In practice, including in Indonesia, the already installed submarine cables is one of the factors considered by the coastal state in determining the designated function of a zone. ${ }^{55}$

Referring to the previous discussion, we can infer that UNCLOS 1982 does not grant the coastal states the right to control the marine space through permit instruments (i.e., acting as the owner). Practice in several countries demonstrates that the MSP policy is often followed by a licensing regime (which correlates with the obligation to acquire a permit, imposition of fees, and taxes). ${ }^{56}$ Such practices contradict UNCLOS 1982 provisions, as mentioned in the first discussion.

Pursuant to the amendment of the Marine Affairs Law in 2020 (by Law No. 11/2020), Indonesia also adopts a licensing regime in exercising its MSP, particularly in this case, regarding the utilization of marine space for submarine cables in the EEZ. Such provision is stipulated under Article 47A (1) of Marine Affairs Law, which mandates the marine location permit to be issued according to

52 Fadli and Raras Cahyafitri, "Indosat Spends Rp10 Billion Replacing Stolen Underwater Cable”, The Jakarta Post, Saturday, 29 June 2013, https://www.thejakartapost.com/news/2013/06/29/indosat-spends-rp-10-billionreplacing-stolen-underwater-cable.html, Accessed on 27 January 2020.

53 Government Regulation on Marine Spatial Planning in Article 96 regulates that the zoning for submarine pipelines and cables considers several criteria, including the suitability for location and safety from disasters at sea.

54 Government Regulation on Marine Spatial Planning in under Article 56 (4a) regulates that in determining the pattern of a marine spatial plan should consider, among others: the rights of other countries in the form of freedom of navigation, flight, placement of submarine cables/pipes, and other marine uses related to these freedoms under international law.

55 Three stages should be fulfilled in planning an MSP. The stages are (1) research and scheming, (2) policy implementation, and (3) monitoring and evaluating. The evaluation results will be considered for the other research and planning stage in the future, making the stage itself a recurring process. See: F. Douvere, "The Importance of Marine Spatial Planning in Advancing Ecosystem-based Sea Use Management," Marine Policy, Vol. 32, No. 5, 2008, pp. 762-771.

56 Nengye Liu, "China's National Plan for Marine Spatial Planning," IUCNAEL EJournal, vol. 7, pp. 179183; Kent Bressie and Madeleine Findley, 2012, "Coping with India's New Telecom: Equipment Security Requirements and Indigenous Innovation," Submarine Telecoms Forum, No. 62, Wayne Nielsen, Virginia, p. 17; Tara Davenport, "Submarine Communications Cables and Law of the Sea: Problems in Law and Practice," Ocean Development \& International Law, 2012, p. 212. 
the MSP in place. However, the findings in the previous discussion suggest that the marine location permit is not compatible with UNCLOS 1982, thus it should not be used as an implementing tool for MSP .

The implementation of MSP policy in EEZ should not be based on the conventional administrational permits as implemented in the territorial water and land spatial planning. There should be a separation in the regulatory regime, whereas the EEZ regulatory regime must consider and adapt to the area's specifics. In this case, the law should consider that Indonesia is not the legal owner of the EEZ and that every state has the freedom to carry out submarine cable laying activity in the EEZ. Therefore, a regulatory regime concerning permits should not be imposed on the region. ${ }^{57}$

Even though the coastal state cannot 'legally enforce' the compliance to the MSP with a licensing regime as a control mechanism, the authors believe that the application of MSP policy in EEZ can rely solely on the duty of due regard duty by the other states in ensuring the protection of the interests of Indonesia.

The MSP acts as the guideline for all other states wanting to exercise their freedom in the Indonesian EEZ as a form of respect (due regard) to coastal states' interests in economic exploitation and marine conservation. Therefore, any incompliance to Indonesia's MSP policy in the EEZ can be considered a failure by the other states to perform their duty of due regard.

In respect to a conflict that arises relating to the compliance with the MSP, Indonesia would have a greater legal standing as it has performed its duty of due regard in the making policy. So long as Indonesia can prove that the other states' rights have been considered and accommodated in the designing and implementing of the MSP, the duty of due regard is arguably satisfied.

On the other hand, other states that object to the maritime zoning as mapped in the MSP would have weaker legal standing as they are considered to have acknowledged the map and zones contained in the MSP and thus triggered an obligation for them to exercise their right in the available zones. ${ }^{58}$

Although an obligatory licensing regime cannot be applied, the other states would still have an inherent obligation to notify the coastal state regarding their plan to install submarine cable through the designated routes. It also should be considered that the coastal state has the right to request notification prior to the activities.

Requesting notification cannot be interpreted as a form of licensing, rather as an attempt by the state to inform that submarine cable installation activities will be carried out, which is still a form of respect by the other states for the rights obligations of the coastal state. ${ }^{59}$ The notification itself is vital 
for the coastal state to be able to record any installation or activity in a marine space so that the other users may also be informed and can adjust accordingly, and also for the coastal state to evaluate the existing MSP and the basis to determine the update to the MSP. ${ }^{60}$

Notification is also needed when the operator or the submarine cable owner intends to remove the cables so that the coastal state authority can accommodate them into the updated map. The notification towards the coastal state is an integral part of the cable owner's duty of due regard. ${ }^{61}$ Should the notification needs to be replied to by the coastal state, then the reply notification cannot be interpreted as a form of granting permission but rather as a confirmation that the notification has been received.

On the other side, the designation of marine spaces into zones according to their intended function would also guarantee certainty and transparency for other states regarding which area is available to be utilized for a specific activity. The MSP instrument would give clear parameters for other states in exercising their duty of due regard as it would be satisfied if they comply with the designated function of the zone.
In contrast, the practice of requiring a permit and the 'prior consent' requirement as prerequisites to lay submarine cables would cause uncertainty for the other states as it gives discretion to the coastal state to decide on a case per case basis. ${ }^{62}$ Meanwhile, with MSP in place, other states would get certainty as to which zones are available for them to install their submarine cables and would enable them to conduct their activity without the need for permission or approval as long as it is done in the appropriate zones. It would also greatly simplify the administration process, as the MSP itself should only require the other state to notify the coastal state about the activity and not oblige them to acquire a permit.

The practice of requiring notification is common in regulating activities at sea. For example, it can be observed in the practice of the innocent passage through the territorial water by foreign war vessels. Although every state is entitled to the right of innocent passage, such passage should be notified to the coastal state before entering the territorial sea when it comes to foreign war vessels. ${ }^{63}$

The notification is not required to be performed in a formal manner. The notification can be carried out by issuing a

60 Government Regulation on Marine Spatial Planning under Article 53 (7d) stipulated that one of the zoning objectives is to direct the submarine cable trajectory in the EEZ with regard to the existing pipelines or submarine cable installed.

61 Tullio Treves, loc.cit.

62 India and Chinese example, see: Kent Bressie and Madeleine Findley, loc. cit.; See also: F. Douvre, Op. Cit., pp. 762-771.

63 Sam Bateman, "UNCLOS and Its Limitations as the Foundation for a Regional Maritime Security Regime," Institute of Defense and Strategic Studies Singapore, April 2006, p. 11; Further see: Jing Geng, "The Legality of Foreign Military Activities in the Exclusive Economic Zone under UNCLOS," Merkourios Utrecht Journal of International and European Law, vol. 28, no. 74, 2012, pp. 22-30. 
briefing note to the local navy authority to prevent misunderstanding. ${ }^{64}$ This form of notification has been recognized by more than 40 countries, including Indonesia. ${ }^{65}$

The findings above show that requiring prior notification is common and even had been implemented by Indonesia. Therefore, a similar mechanism can be adopted for the submarine cable provisions under the MSP policy. ${ }^{66}$ The practice of requiring prior notification should be formalized into a legal framework that would provide legal certainty and the legal procedure in exercising the right of submarine cable laying within Indonesian EEZ. The prior notification could be utilized to substitute the marine location permit instrument to regulate and control MSP implementation, particularly in the jurisdiction water territory.

Another aspect to consider is how Indonesia should declare or publish the existence of its MSP policy in its EEZ. In practice, a state planning to lay submarine cable commonly conduct prior research on the relevant regulation applied by other states, considering the regulation between countries may vary. Hence, the very existence of the zissued legal instrument such as the Government Regulation No. 32/2019 concerning MSP itself would constitute a way for Indonesia to announce its MSP applicable in its marine territory. ${ }^{67}$

However, it would be better if the documents related to the MSP (i.e., zoning maps) be communicated through relevant international organizations channels, for example, the International Cable Protection Committee (ICPC) and the IOC-UNESCO's Marine Spatial Planning Program, each of which is closely related to submarine cabling activities and the implementation of MSP around the world.

64 Ibid.; as an example, China had declared against the UNCLOS 1982 that coastal states have the right to request other states to have prior approval from the government or issue a prior notification to the coastal state when their war vessel traversed over the territorial water of the coastal state.

65 Ibid.; Such provision was implemented in Indonesia through the Government Regulation No. 8/1962 on the innocent passage of foreign war vessel in internal water. Article 7 (1) stipulates that before traversing into Indonesian internal water, foreign war vessel or foreign government vessel should notify the Minister or the Chief of Staff of the Indonesian Navy unless the passage is conducted through channels that have been or will be determined by the Minister or the Chief of Staff of the Indonesian Navy. Although the regulation itself has been repealed, the very existence of the regulation itself shows that Indonesia once implemented a prior notification mechanism in the past, and thus it is not entirely a new concept.

66 The Standard Operating Procedure for laying submarine cables in territorial and jurisdictional areas has not been expressly regulated in practice. Nevertheless, the practice of laying submarine cables in the territorial sea and territorial jurisdiction has been going on for a long time. Referring to the information from the Marine Space Utilization Licensing Department, Directorate of Marine Spatial Planning, Ministry of Marine Affairs and Fisheries, it is explained that a series of processes generally followed by business entities (operators) that will install submarine cables are as follows: (1) conducting site visits at landing points and conducting coordination meetings with relevant local authorities, (2) obtaining technical recommendations from the local navigation district, (3) getting recommendations on safety aspects from the local authority, and (4) obtaining a marine space utilization permit from the local, provincial government.

67 Considering Government Regulation No. 8/1962, which was solely directed at foreign state vessels, was exclusively meant to be a reference for the other countries. Therefore, it can be concluded that the issuance of Government Regulation on Marine Spatial Planning itself can be assumed to be acknowledged by other states just by issuing the regulation. Thus, the burden to seek information regarding the applicable regulations is on the foreign state entities. 
According to the findings thus far, it can be concluded that the MSP instrument is in line with the provisions stipulated in the UNCLOS 1982 as it accommodates other states' right to lay submarine cables (i.e., as the implementation of due regard), and it would not put Indonesia above the other state in the ownership of EEZ. It is important to note that the implementation of MSP in the EEZ should not be followed by the administration licensing regime. Instead, it may be followed by implementing the prior notification mechanism to monitor the compliance to the MSP in place.

\section{Conclusion}

1. Marine location permit is not the appropriate instrument for Indonesia to safeguard its economic interest in the EEZ, as it is incompatible with UNCLOS 1982 regarding the specific characteristics of EEZ and disregards the existence of other states' freedom.

2. The marine spatial planning instrument is the appropriate instrument for Indonesia to safeguard its economic interests in the
EEZ, as it is compatible with UNCLOS 1982 regarding the specific characteristics of EEZ, and it may also constitute as a form of duty of due regard. However, the implementation of the MSP should not be followed by licensing regime (i.e., marine location permit instrument).

\section{Recommendation}

1. The Indonesian government needs to provide an exception clause regarding the submarine cable laying activity in the EEZ in the draft Government Regulation on marine location permit.

2. The Indonesian government needs to formulate and formalize the procedure for implementing the prior notification requirement by other states in the MPS policy operating instrument in the Indonesian EEZ as a reference for other countries.

3. The Indonesian government must publish its MSP policy and the maps in its annex through international organizations such as the ICPC and IOC. 


\section{BIBLIOGRAPHY}

\section{Book Sources}

Asia-Pacific Economic Cooperation. Economic Impact of Submarine Cable Disruptions. APEC Policy Support Unit, Bangkok: Detecon Asia-Pacific Ltd. 2012.

Ehler, C.N., and F. Douvere. Visions for a Sea Change, Report of the First International Workshop on Marine Spatial Planning. Intergovernmental Oceanographic Commission and man and the biosphere programme, IOC Manual and Guides No. 48 IOCAM Dossier No. 4, UNESCO, 2007.

Shaw, Malcolm N. International Law 7th Edition, Cambridge: Cambridge University Press, 2014.

\section{Book Chapter}

Carter, Lionel. et al. "The Relationship between Submarine Cables and the Marine Environment," in Douglas R. Burnet et al. (eds). Submarine Cables: The Handbook of Law and Policy. Martinus Nijhoff Publisher. 2014.

Djalal, Hasjim, “'Due Regards' and Abuse of Rights in UNCLOS," in Shicun Wu et al. (eds). UN Convention on the Law of the Sea and the South China Sea, National Institute for South China Sea Studies, Ashgate Publishing Limited. 2015.

\section{Journal Sources}

Bateman, Sam. "UNCLOS and Its Limitations as the Foundation for a Regional Maritime Security Regime," The Korean Journal of Defense Analysis, Vol. 19, No. 3, (April 2007): 27-56.

Becker-Weinberg, V. "Preliminary Thoughts on Marine Spatial Planning in Areas beyond National Jurisdiction." The International Journal of Marine and Coastal Law, Vol 32, No 3, (2017): 570-588.

Davenport,Tara. "SubmarineCommunications Cables and Law of the Sea: Problems in Law and Practice." Ocean Development \& International Law, Vol. 43, No. 3. (2012): 201-242

Douvere, F. “The Importance of Marine Spatial Planning in Advancing Ecosystembased Sea Use Management," Marine Policy, Vol. 32, No. 5, (2008): 762-771. Ehler, Charles N. "An International Perspective on Marine Spatial Planning Initiatives," Environments Journal, Vol. 37, No. 3, (2010): 9-20.

Gaunce, Julia. "On the Interpretation of the General Duty of 'Due Regard," Ocean Yearbook, Vol. 32, No. 1, (2017): 27-59. Geng, Jing. "The Legality of Foreign Military Activities in the Exclusive Economic Zone under UNCLOS," Merkourios Utrecht Journal of International and European Law, Vol. 28, no. 74, (2012): 22-30. 
Liu, Nengye. "China's National Plan for

Marine Spatial Planning," IUCNAEL E-Journal. Vol. 7, (2016): 179-183.

Maes, Frank. "The International Legal Framework for Marine Spatial Planning," Marine Policy, vol. 32, no. 5, (2008): 797-810.

Mudrić, Mišo. "Rights of States Regarding Underwater Cables and Pipelines," Australian Resouces and Energy Law Journal, Vol. 29, No. 2, (2010): 235.

Takei, Yoshinobu. "Law and Policy for International Submarine Cables: An Asia-Pacific Perspective," Asian Journal of International Law, Vol. 2, No. 2. (2012): 205-233.

Treves, Tullio. “Coastal States' Rights in the Maritime Areas under UNCLOS," Brazilian Journal of International Law, Vol. 12. No. 1, (2015): 12-40.

Tuda, A. O., et al., "Resolving Coastal Conflicts using Marine Spatial Planning," Journal of Environmental Management, Vol. 133 (2014): 59-68

\section{Scientific Article Sources}

Beckman, Robert. Submarine Cables - A Critically Important but Neglected Area of the Law of the Sea, presented at ISIL Conference, January (2010).

Bressie, Kent, and Madeleine Findley. Coping with India's New Telecom: Equipment Security Requirements and Indigenous Innovation, presented at Submarine Telecoms Forum Virginia (2012).

\section{Indonesian Laws}

Government Regulation Number 32 of 2019 on Marine Spatial Planning

Law Number 30 of 2014 on State Administration.

Law Number 32 of 2014 on Marine Affairs.

\section{Treaties and International Court}

\section{Rulings}

ITLOS. Case No. 16. "Dispute concerning delimitation of the maritime boundary between Bangladesh and Myanmar in the Bay of Bengal (Myanmar v. Bangladesh)." Judgment of March 2012.

ITLOS. Case No. 2. 'M/V 'SAIGA' (Saint Vincent and the Grenadines v. Guinea)." Separate Opinion of Judge Laing, Judgment of 1 July 1999.

PCA. Case No. 2011-03. "The Chagos Marine Protected Area Arbitration (Mauritius v. UK). Award of 18 March 2015.

United Nations Convention on the Law of the Sea.

\section{Internet Sources}

CNN Indonesia. "Kominfo Bakal Tata Ulang Kabel Optik Bawah Laut", https://www.cnnindonesia.com/tekno logi/20180928170137-213-334042/ kominfo-bakal-tata-ulang-kabel-optikbawah-laut. Accessed 12 December 2019.

Fadli, and Raras Cahyafitri. "Indosat Spends Rp10 Billion Replacing Stolen 
Underwater Cable", The Jakarta Post, 29 June 2013, https://www. thejakartapost.com/news/2013/06/29/ indosat-spends-rp-10-billionreplacing-stolen-underwater-cable. html. Accessed 27 January 2020

Green, Mick P., and Douglas R. Burnett, "Security of International Submarine Cable Infrastructure: Time to Rethink?" International Cable Protection Committee, available online at https://www.iscpc.org/information/ government-and-law/. Accessed 29 January 2020.

Intergovernmental Oceanographic Commission - United Nations Educational. Scientific, and Cultural Organization, Marine Spatial Planning Programme, http://msp.ioc-unesco. org/world-applications/overview/. Accessed 29 January 2020

Liputan 6. "Perusahaan Indonesia Garap Proyek Kabel Listrik Bawah Laut Malaysia-Singapura". https://www. liputan6.com/ bisnis/read/4102965/ perusahaan-indonesia-garap-proyekkabel-listrik-bawah-laut-malaysiasingapura. Accessed 28 November 2019.

Ramadhani, Mutia. "Indonesia-Singapore Underwater Networks Disrupted after Anchor Snags Cable." Republika. https://republika.co.id/berita/muvd9b/ indonesiasingapore-underwaternetworks-disrupted-after-anchorsnags-cable. Accessed 27 January 2020. 